\title{
PENERAPAN METODE EKSPERIMEN BERBASIS LABORATORIUM VIRTUAL UNTUK MENINGKATKAN KETERAMPILAN MENGAJAR GURU FISIKA SMA SE-KABUPATEN LOMBOK UTARA
}

\author{
Lily Maysari Angraini ${ }^{1}$, Rahadi Wirawan ${ }^{1 *}$, Nurul Qomariyah¹ \\ 1.Program Studi Fisika, Fakultas Matematika dan IImu Pengetahuan Alam Universitas Mataram \\ ${ }^{*}$ Co-Author :rwirawan@unram.ac.id
}

\begin{abstract}
ABSTRAK. Tujuan kegiatan pengabdian ini adalah memperkuat konsep metode pembelajaran eksperimen dengan mengembangkan laboratorium virtual sebagai solusi ketidaktersediaannya alat praktikum dan sekaligus untuk meningkatkan keterampilan mengajar guru fisika SMA se-kabupaten Lombok Utara. Kegiatan ini dilaksanakan di SMA Negeri 1 Tanjung Kabupaten Lombok Utara, dengan peserta guru-guru fisika yang tergabung dalam MGMP mata pelajaran fisika SMA kabupaten Lombok Utaran. Metode yang digunakan dalam kegiatan ini adalah metode FGD dan Direct Instruction, metode demonstrasi dan metode Problem Based Learning (PBL). Adapun perancangan laboratorium virtual pada kegiatan ini menggunakan software LabVIEW 8.5 dan Arduino Uno. Hasil kegiatan ini tersusunnya perencanaan pembelajaran fisika menggunakan metode eksperimen berbasis laboratorium virtual, terinstalasinya program LabVIEW dan Arduino Uno di laptop masingmasing peserta, terbangunnya sebuah prototype system pengukuran jarak menggunakan sensor ultrasonic BMP05 dari kerja masing-masing kelompok, dan meningkatnya keterampilan guru mengajar fisika dengan metode eksperimen berbasis LabVIEW.
\end{abstract}

Kata Kunci: Pembelajaran Fisika, Metode Eksperimen, Laboratorium Virtual, LabVIEW, Arduino

ABSTRACT. The purpose of this service activity is to strengthen the concept of experimental learning methods by developing virtual laboratories as a solution to the unavailability of experiment tools and at the same time to improve the teaching skills of high school physics teacher throughout North Lombok. This activity was carried out in SMA 1 Tanjung North Lombok regency, with participant of physics teacher who joined the MGMP North Lombok. The method used in this activity are the FGD and direct instruction method, demonstration methods and problem based learning methods. The design of virtual laboratories in this actibity uses software LabVIEW 8.5 and Arduino Uno. The results of this activity are arranged physics learning planning using a virtual laboratory-based experimental method, the installation of LabVIEW and Arduino Uno programs on each participant's laptop, the establishment of a distance measurement system prototype using BMP05 ultrasonic sensors from each group work, and increasing teacher teaching physics skill with LabVIEW-based experimental method.

Keyword: physics learning, experiment method, virtual laboratory, Lab VIEW, Arduino Uno.

\section{PENDAHULUAN}

Pemahaman yang terbangun secara utuh dalam bidang ilmu fisika dan aplikasi pengembangannya didasari oleh hasilhasil eksperimen yang dilakukan (Ariswan, 2016). Pembelajaran fisika yang terjadi selama ini hanya berkutat pada penyampaian konsep dan disertai dengan latihan soal. Metode mengajar yang digunakan pada umumnya adalah metode ceramah (Suparno, 2007). Padahal secara harfiahnya pembelajaran sains tidak cukup disampaikan dengan metode tersebut. Menurut UNESCO melalui "The International Commission on Education for the Twenty First Century" merekomendasikan pendidikan yang berkelanjutan (seumur hidup) yang dilaksanakan berdasarkan empat pilar proses pembelajaran, yaitu: Learning to know (belajar untuk menguasai pengetahuan), learning to do (belajar untuk menguasai keterampilan), learning to be (belajar untuk mengembangkan diri), dan learning to live together (belajar untuk hidup 
bermasyarakat). Untuk dapat mewujudkan empat pilar pendidikan tersebut, para guru sebagai agen pembelajaran perlu menguasai dan menerapkan multimedia interaktif dalam pembelajaran di sekolah (Hernawan, 2008).

Salah satu bentuk multimedia interaktif adalah alat peraga sebagai bagian dari media pembelajaran(Saroja, dkk, 2014). Alat peraga biasanya digunakan untuk proses penggalian konsep pada siswa. Akan tetapi alat-alat peraga yang digunakan ini memiliki keterbatasan yaitu hanya bisa menunjukkan gejala fisisnya saja. Sedangkan penggambaran hubungan antara besaran-besaran lainnya tidak bisa diperlihatkan. Adanya keterbatasan alat peraga ini yang digunakan akan menghambat dalam proses penanaman konsep yang optimal.

Selain alat peraga, proses penguatan konsep untuk siswa dapat juga dilakukan melalui kegiatan praktikum. Kegiatan praktikum pada hakikatnya merupakan impelementasi dari learning to do yaitu belajar untuk menguasai keterampilan. Merefleksi tujuan pembelajaran IPA disekolah dasar dan menengah (Murphy, 2006) yaitu untuk mengembangkan kemampuan proses ilmiah (skill), mendorong pemahaman konsep, dan mengembangkan sikap positif terhadap ilmu pengetahuan. Oleh karenanya, kegiatan praktikum atau eksperimen merupakan kegiatan yang tidak bisa dipisahkan dalam proses pembelajaran sains umumnya dan fisika khususnya(Triwoyono, 2011).

Terdapat banyak kendala yang dialami para guru dalam memaksimalkan kegiatan praktikum siswa, diantaranya keterbatasan alat-alat praktikum di laboratorium. Hal ini juga dialami oleh guru fisika SMA di wilayah Kecamatan Tanjung, Kabupaten Lombok Utara. Untuk mengatasi keterbatasan tersebut, maka kami selaku tim pengabdian pada masyarakat bidang minat instrumentasi dan komputasi fisika Fakultas Matematika dan IImu Pengetahuan Alam (FMIPA) Universitas Mataram mencoba untuk mengembangkan media pembelajaran praktikum berbasis simulasi komputer yang salah satunya adalah media simulasi laboratorium virtual berbasis lab view. Virtual lab merupakan produk hasil teknologi yang dapat digunakan untuk metode eksperiment sebagai alternative kekurangan alat alat laboratorium (Salam dkk, 2010).

Laboratorium virtual merupakan serangkaian alat-alat laboratorium yang berbentuk perangkat lunak, dioperasikan dengan komputer dan dapat mensimulasikan kegiatan dilaboratorium seakan-akan pengguna berada pada laboratorium sebenarnya. Penggunaan laboratorium virtual pada pembelajaran interaktif dapat lebih efektif mengembangkan pemahaman konsep, utamanya pada kemampuan translasi, interpretasi dan ekstrapolasi, serta dapat mengembangkan kemampuan soft skill khususnya scientificskill (Sinaga, 2010). Laboratorium virtual mampu memberikan peningkatan secara signifikan dan pengalaman belajar yang lebih efektif, sehingga pengembangan laboratorium virtual ini diharapkan dapat menyelesaikan permasalahan belajar yang dialami peserta didik dan mengatasi permasalahan biaya dalam pengadaan alat dan bahan yang digunakan untuk mengadakan kegiatan praktikum untuk sekolah-sekolah yang memiliki peralatan laboratorium yang kurang memadai.

LabVIEW (Laboratory Virtual Instrument Engineering Workbench) adalah bahasa pemrograman grafis yang menggunakan ikon bukan baris teks untuk membuat aplikasi. Software ini digunakan khusus untuk pemrosesan dan visualisasi data dalam bidang akuisisi data, kendali dan instrumentasi, serta otomatisasi industri. Berbeda dengan bahasa pemrograman berbasis teks dimana petunjuk menentukan eksekusi program LabVIEW menggunakan data flow pemrograman, di mana aliran data menentukan eksekusi(Dian, 2012).

Pengembangan laboratorium fisika virtual berbasis labview mempunyai keunggulan berupa kemudahan dalam menciptakan instrumentasi virtual yang estetis tampak seperti instrumentasi nyata tetapi dikendalikan dengan program komputer yang canggih dan dapat membuat simulasi (Melinda, 2017). LabVIEW merupakan suatu bahasa pemrograman yang sudah berorientasi objek grafis yang memfasilitasi perangkat keras dan perangkat lunak. Dengan demikian laboratorium virtual yang akan dikembangkan tidak hanya sebatas pada softwarenya akan tetapi juga akan dikembangkan interaksi sistem kontrol dalam hal ini arduino dengan labview (Dian, 2012). Hal ini akan lebih memudahkan bagi peserta didik dan guru dalam belajar dan membelajarkan fisika. 


\section{ANALISIS PERMASALAHAN}

Berdasarkan latar belakang permasalahan yang dipaparkan di atas dan sesuai hasil observasi yang dilakukan melalui wawancara dengan ketua MGMP mata pelajaran Fisika SMA Kabupaten Lombok Utara yaitu Bapak Suhaili S.Pd, secara umum permasalahan yang dihadapi oleh guru-guru fisika SMA Kabupaten Lombok Utara adalah: pertama kurangnya kegiatan praktikum dalam pembelajaran fisika. Hampir sebagian besar sekolah menengah khususnya di sekolah-sekolah yang termasuk dalam daerah kategori $3 T$ tidak pernah melakukan pembelajaran berbasis praktikum atau eksperimen. Sehingga siswa kurang memahami konsep dan teori fisika. Kedua yaitu keterbatasan alat-alat praktikum fisika serta keterbatasan biaya dalam pengadaan alat dan bahan yang digunakan untuk mengadakan kegiatan praktikum untuk sekolah-sekolah yang kurang mampu.

Alasan utama tidak terlaksananya pembelajaran berbasis eksperimen adalah kurangnya peralatan praktikum yang memadai serta kurangnya keterampilan guru dalam merancang pembelajaran berbasis eksperimen. Peralatan praktikum dasar untuk sekolah di daerah $3 \mathrm{~T}$ memang minim. Jikapun ada, peralatan tersebut hanya diberikan tanpa adanya pelatihan yang berkelanjutan. Kondisi ini diperparah dengan kurangnya keterampilan guru dalam merancang pembelajaran berbasis alat eskperimen. Sehingga pembelajaran siswa hanya ditekankan pada penguasaan teori yang ada di buku teks, latihan soal dan tugas. Dengan demikian, evaluasi pembelajaran hanya bisa dinilai dari aspek kognitif saja. Padahal jika merujuk pada konsep pembelajaran fisika yang telah dipaparkan dibagian pendahuluan, metode pembelajaran yang diterapkan belum bisa mengkontruksi pemahaman konsep fisis siswa.

\section{SOLUSI YANG DITAWARKAN}

Berdasarkan rincian permasalahan yang dihadapi guru fisika SMA Kabupaten Lombok Utara tersebut, maka berikut beberapa solusi yang ditawarkan yaitu pertama memberikan pelatihan kepada guru untuk menyusun pembelajaran berbasis learn to do yang dapat diimplementasikan dengan menggunakan metode eksperimen atau metode laboratorium. Kedua memberikan pelatihan dasar-dasar pengembangan laboratorium virtual berbasis lab view untuk mengatasi keterbatasan alat-alat praktikum fisika. Adapun pelatihan dasar yang diberikan meliputi teori sistem kontrol, sensor, arduino, dasar-dasar LabVIEW, serta membuat aplikasi sederhana berbasis LabVIEW.

\section{Tahap 1}

Menjelaskan konsep metode pembelajaran eksperimen dan pengenalan lab view dan system kontrol. Tahap ini disajikan dengan metode direct instruction. Pada tahap ini, peserta kegiatan diberikan penguatan tentang apa itu metode pembelajaran ekserimen, langkah-langkah pembelajaran serta mengelompokkan kata-kata operasional yang digunakan dalam merancang pembelajaran menggunakan metode tersebut. Untuk lebih efektif dan efesien, metode penyampaian yang digunakan pada tahap ini adalah metode FGD. Peserta membagi pengalaman dalam merancang proses pembelajaran yang dilakukan selama ini serta mengungkapkan kendala yang dihadapi. Permasalahan ini akan ditanggapi oleh peserta lain berupa berbagi pengalaman yang lain atau berupa solusi dari permasalahan yang dihadapi.

\section{Tahap 2}

Instalasi software lab view dan arduino. Software tersebut dibagikan via flash disk ke masing-masing peserta, kemudian dengan metode demonstrasi, peserta di bimbing instalasi software langkah per langkah.

\section{Tahap 3}

Mendemokan beberapa kasus untuk memberi contoh penggunaan aplikasi tersebut. Adapun kasus-kasus yang ditampilkan adalah proses matematis dengan menggunakan lab view, merancang alat dan bahan praktikum dan menghubungkan sistem kontrol dengan lab view. 


\section{Tahap 4.}

Pemberian permasalahan yang harus diselesaikan oleh masing-masing kelompok. Tahap ini dilakukan dengan menggunakan metode PBL (Problem Based Learning). Masing-masing kelompok diberikan dua permasalahan yaitu bagaimana caranya membuat virtualisasi alat pengukur suhu menggunakan sensor LM35 dan pengkur jarak menggunakan sensor jarak BMP05. Setiap peserta diberikan modul panduan arduino dan lab VIEW. Setiap peserta didampingi oleh satu orang mahasiswa.

\section{HASIL DAN PEMBAHASAN \\ Metode Pembelajaran Eksperimen Berbasis Virtual Lab.}
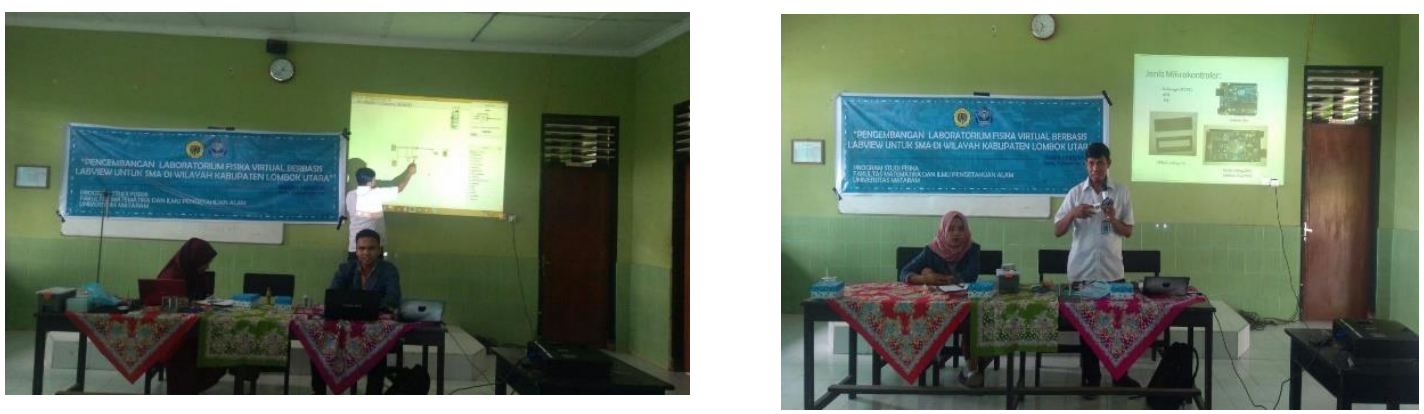

Gambar 1. Penyampaian materi (a) konsep pembelajaran eksperimen dan (b) konsep-konsep dasar lab view dan mikrokontroler

Tampak pada gambar, salah satu tim pengabdian sebagai nara sumber tengah menjelaskan konsep-konsep pembelajaran eksrimen dan konsep-konsep dasar mikrokontroler. Pembelajaran berbasis eksperimen adalah pembelajaran yang menggunkan alat peraga sebgai media pembelajaran guna memudahkan siswa untuk memahami konsep materi yang diajarkan. Mikrokontroler adalah sebuah sistem computer fungsional dalam sebuah chip dan di dalamnya terkandung sebuah inti prosser, memori (sejumlah kecil) RAM, memori program, atau keduanya, dan perlengkapan input-output. LabVIEW merupakan perangkat lunak yang khusus digunakan untuk pemrosesan dan visualisasi data dalam bidang akuisisi data, sistem kontrol, sistem instrumentasi, serta otomatisasi

\section{Proses Instalasi LabView dan Arduino Uno}

Dalam proses instalasi masing-masing kelompok didampingi satu orang mahasiswa, untuk memandu langkah-langkah instalasi kedua program tersebut. 


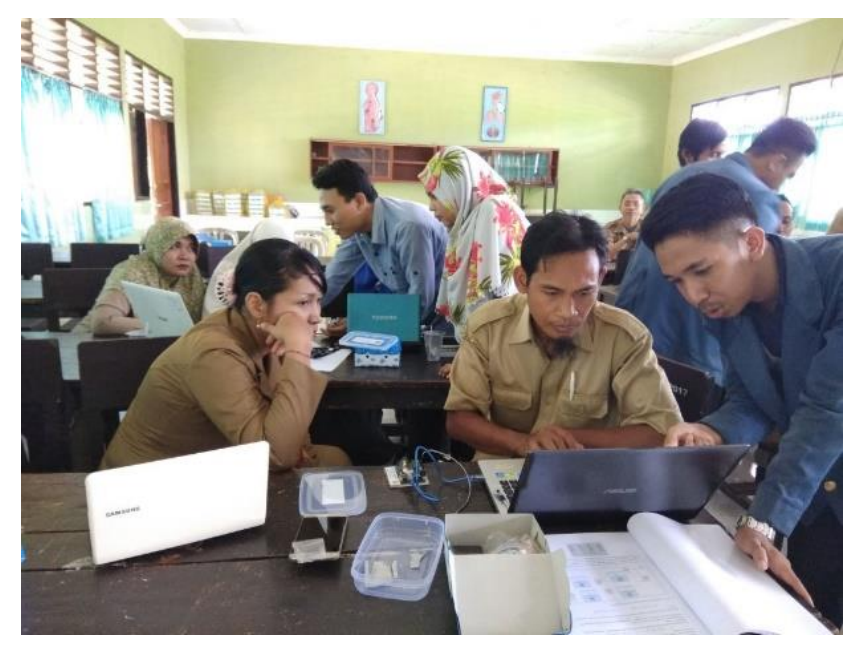

Gambar 2. Pendampingan oleh mahasiswa dalam Proses Instalasi program LabVIEW dan Arduino

Pada gambar 2, tampak peserta antusias mengikuti arahan dari pendamping untuk mengklik langkah per langkah instalasi program. Metode pendampingan untuk setiap kelompok merupakan metode yang sangat efektif. Mengingat kegiatan ini merupakan kali pertama bagi para peserta mengenal program LabVIEW dan program arduino. Maka dari itu, tim pengabdian memfasilitasi para peserta dengan masing-masing satu orang pendamping guna mengatasi kebingungan atau miskonsepsi dalam memahami materi pelatihan.

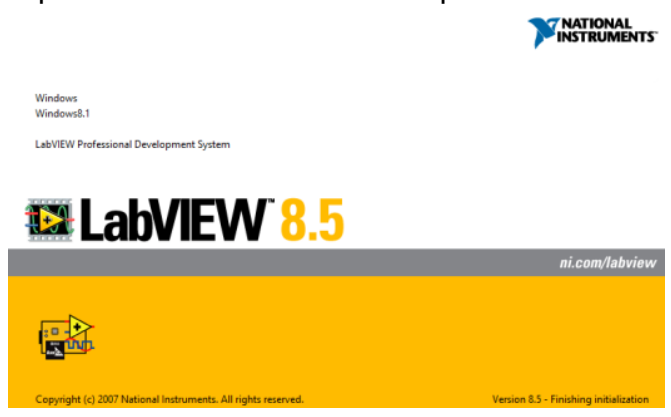

(a)

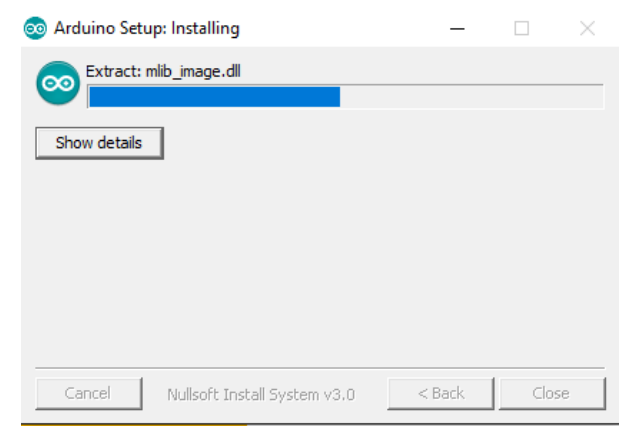

(b)

Gambar 3. (a) Program LabVIEW setelah diinstalasi, (b) proses instalasi program arduino uno

\section{Demonstrasi Project Sederhana dengan Menggunakan LabVIEW.}

Setelah proses instalasi selesai, tim pengabdian mendemonstrasikan cara penggunakan LabVIEW dengan memberikan contoh project sederhana. Ada dua project sederhana yang didemonstrasikan yaitu (1) proses penjumlahan sederhana, (2) penyimpanan data ke excel. 


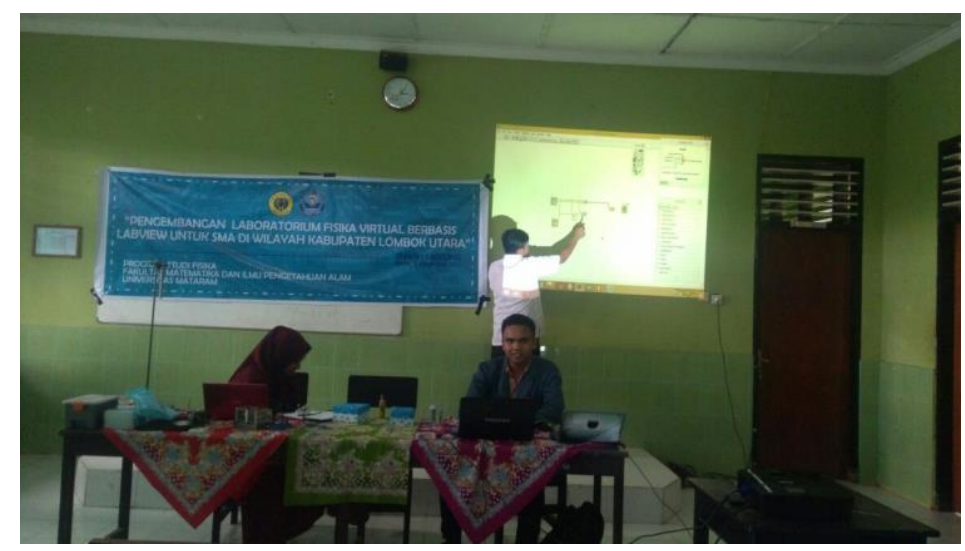

Gambar 4. Pembuatan visualisasi proses penjumlahan sederhana

Dalam project ini, hal yang harus dipahami oleh para peserta adalah memahami nama dan fungsi tombol atau pallete yang akan digunakan. LabVIEW dilengkapi dengan berbagai fitur tombol yang bisa digunakan sesuai dengan kebutuhan.

\section{Pembuatan Project Sederhana di masing -masing kelompok}

Untuk pembuatan project sederhana, setiap kelompok diberikan 1 buah modul arduino uno yang dilengkapi dengan 1 buah sensor suhu LM35 dan 1 buah sensor jarak BMP05.

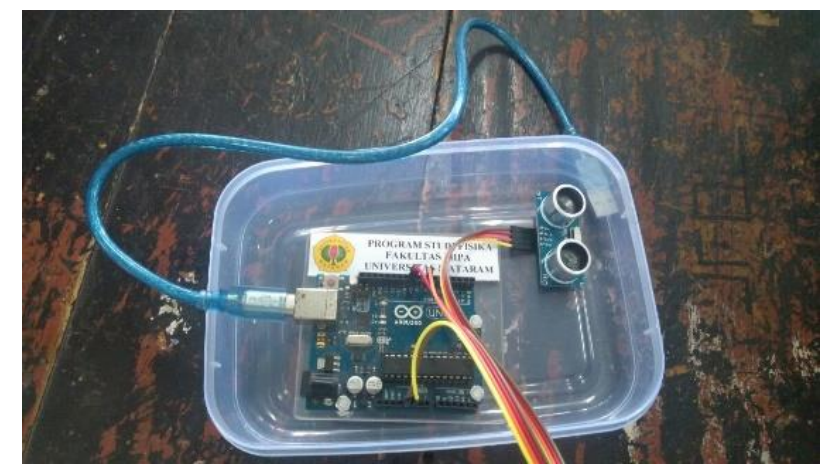

Gambar 5. Modul Arduino Uno, Sensor suhu LM35 dan sensor jarak BMP05

Ada dua project yang akan dibuat yaitu pengukuran jarak menggunakan sensor BMP05 dan pengukuran suhu menggunakan sensor suhu LM35. 


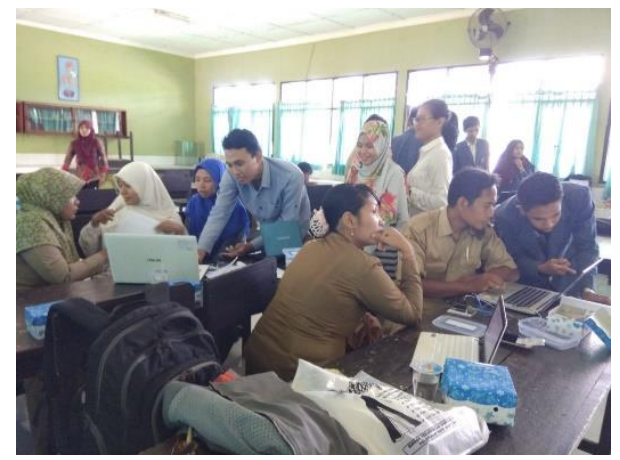

(a)

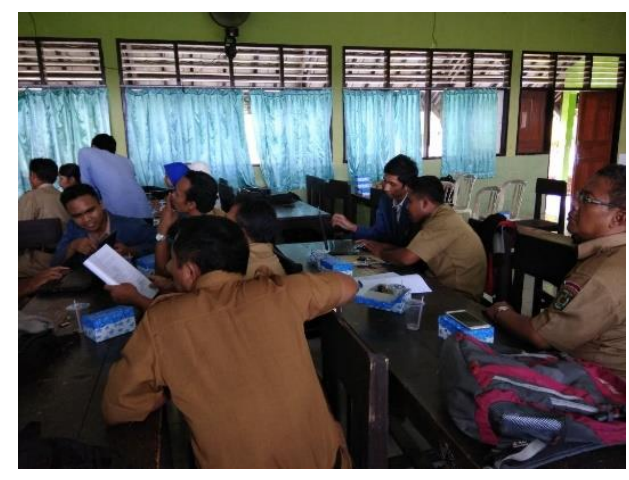

(c)

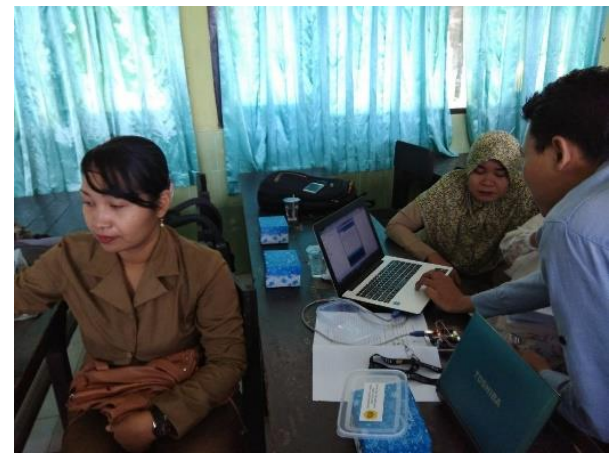

(b)

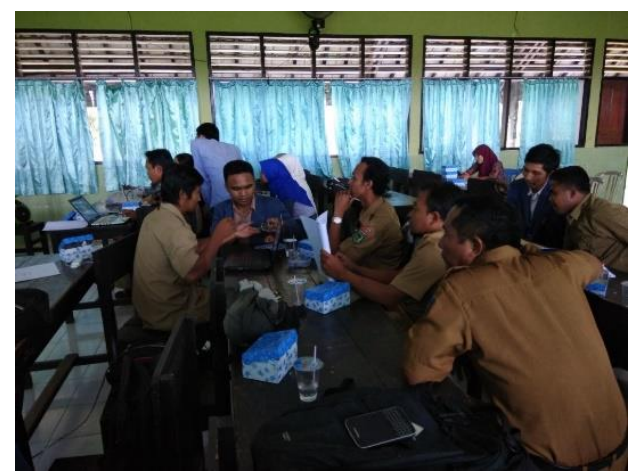

(d)

Gambar 6. Pembuatan project masing-masing kelompok (a) kelompok 1, (b) kelompok 2, (c) kelompok 3, dan (d) kelompok 4

\section{KESIMPULAN}

Kegiatan ini dapat memberikan manfaat kepada guru-guru fisika SMA/SMK kabupaten Lombok Utara, yaitu memberikan pengalaman belajar baru terkait dengan motode pembelajaran fisika. Selain itu, guru-guru fisika juga bisa mengatasi keterbatasan peralatan laboratorium dengan cara mengembangkan laboratorium virtual, sehingga nantinua pembelajaran fisika yang sejatinya learn to do dan bersifat konstruktivisme dapat direalisasikan. Dengan demikian, pembelajaran fisika akan menjadi pembelajaran yang menyenangkan dan dapat meningkatkan minat serta prestasi belajar siswa.

\section{UCAPAN TERIMA KASIH}

Ucapan terimakasih kepada Universitas Mataram yang telah mendanai kegiatan pengabdian pada masyarakat melalui sumber pendanaan BOPTN. Selain itu ucapan terimakasih juga kami tujuan kepada Wakil Kepala Sekolah SMA Negeri 1 Tanjung Bapak Drs. Akhmad Raden Saleman, atas kesediaannya sebagai mitra dan memberikan fasilitas berupa ruangan dan perlengkapan lainnya. Ucapan terimakasih juga kami ucapkan kepada ketua MGMP mata pelajaran fisika SMA Kabupaten Lombok Utara. Mudah-mudahan kemitraan ini akan tetap berlanjut sehingga terjalin sinergitas antara masyarakat (dalam hal ini SMA se-kabupaten Lombok Utara) dengan program studi fisika FMIPA Universitas Mataram. Selain itu, kegiatan ini juga diharapkan sebagai implementasi program UNRAM Mengabdi. 


\section{REFERENSI}

Artanto, Dian. 2012. Interaksi Arduino dan LabView. Jakarta : PT Elex Media Komputindo.

Azhar Arsyad. (2003). Media pengajaran. Jakarta: Raja Grafindo Persada.

Paul Suparno. (2007). Metodologi Pembelajaran Fisika Konstruktivisme dan Menyenangkan. Universitas Sanata Dharma Press. Yogyakarta.

Murphy, (2006), The Impact of ICT on Primary Science, New York: Open University Press.

Maulinda. K. R; Ishafit. 2017. Pengembangan Laborotorium Virtual Rangkaian RLC Seri Berbasis LabVIEW Untuk Pembelajaran Fisika SMA. JKRPF UAD Vol. 4 No. 2.

Sinaga, P. 2010. Penerapan Laboratorium Maya Pada Pembelajaran Konseptual Interaktif Fisika Untuk Meningkatkan Pemahaman Konsp dan Mengembangkan Scientific Skill. Fisika FPMIPA UPI.

Salam.H; Setiawan. A; Hamidah. I. 2010.Prosidings of the $4^{\text {th }}$ International Conference On Teacher Education; Join Conference UPI \% UPSI Bandung; Indonesia; 8-10 2010.

Yuliana Subekti, A. Arison. 2016. Pembelajaran Fisika dengan metode eksperimen untuk meningkatkan hasil belajar kognitif dan keterampilan proses sains. Jurnal Inovasi pendidikan IPA, 2(2), 252 - 261.

Triwoyono. 2011. Program pembelajaran fisika menggunakan metode eksperimen terbimbing untuk meningkatkan keterampilan berpikir kritis. Jurnal Pendidikan Fisika Indonesia. 80-83.

Guncang Saroja, Ahmad Nadhir, Sukir Maryanto, Didik Rahadi Santoso, Setyawan P. Sakti. 2014. Pemanfaatan alat peraga untuk proses pembelajaran fisika di SLTA (Studi presepsi guru-guru fisika SLTA di kabupaten Lombok Timur). Journal of education innovation. Vol 2. No 2. $8-12$. 